\title{
Research on Public Computer Course Teaching Reform: One Platform, Different Major
}

\author{
YANG Yanchuna, LI Ying ${ }^{b}$, SUN Hongfeng ${ }^{c}$ and LIU Qian ${ }^{d}$ \\ School of Information Technology, Shandong Women's University, Jinan 250300, China \\ ayych10@126.com, bcherry_jn@126.com, cnameshf@163.com, diuqian_mail@163.com
}

Keywords: public computer course, teaching mode, reform.

\begin{abstract}
The public computer education in university is facing new challenges. Employers require computer application ability of college students, and the requirements differ according to different major. In this paper, a teaching mode reformation was promoted, which combined teaching content with specific major requirement, and during the whole process of teaching linked with various professional practice. In the new teaching mode, students would understand the important role of computer as a professional tool, and they would be taught the process and method on how to use computers to solve professional problems, and grasp the way to obtain professional software. Thus public computer education can better meet the requirements for computer application skills of different major. The reform of teaching mode included designing and development of teaching contents, different multimedia courseware and experiment guide book according to the needs of accounting major and English major.
\end{abstract}

\section{Introduction}

As a university general education curriculum, public computer course plays a very important role for non-computer majors in computer knowledge and ability training. The purpose of teaching is to enable students to master the basic computer application knowledge and basic operation, promotion of non-computer professional information literacy of the students, which develop the students into the new compound talents to meet the needs of various professions. The public computer course faces some new challenges, for examples, employers require more computer application ability of college students, and requirements differ from each other, some of the content has been taught [1] in high middle school. Although the starting point of freshmen has been significantly improved, however, due to various reasons, students differ greatly in computer knowledge and skills.

\section{Present Situation of Teaching in Public Computer Course}

As an occupation technology course, public computer course is a compulsory course mainly to cultivate computer application ability for non-computer majored students, to perfect the computer knowledge structure and improve their ability of computer application. Enable students to have basic skills and sustainable development of the innovation ability, adapting to corresponding post requirements.

To implement the "CPC Central Committee and State Council on deepening education reform and promoting quality education decision" and "The State Council about basic education reform and development of decision", the Ministry of Education decided to vigorously promote basic education curriculum reform, adjust and reform basic education curriculum system, structure, content, construction to meet the requirements of quality education and the new basic education curriculum system.

At present, public computer basic courses in universities have been carried out on the teaching reform of teaching pattern, curriculum evaluation, the evaluation of the teaching, such as Lanzhou University of Finance and Economics[2] analyzed in the course of the outstanding problems and their causes, aiming at solving these problems, from the teaching team, the integration of teaching content, experimental quality, the sharing of teaching resources, teaching material construction, teaching evaluation system in the teaching reform on the course of the six suggestions and thinking; 
Inner Mongolia Normal University[3] put forward "public computer basic course" construction plan, including the characteristics of the curriculum, teaching reform measures, practical teaching and resources construction, and introduces the achievements of curriculum construction; Ningbo University of Technology[4] focus on making some additions and adjustment to the existing teaching content; Career Academy Shandong judicial police officer[5] proposed combination of subject characteristics based on the formulation of curriculum, teaching strategy cyber source utilization; Hubei Radio and TV University[6] improve the public basic computer teaching effect and teaching quality, and ultimately improve their level of computer application and employment ability from the ideological understanding, teaching conditions, teaching, curriculum evaluation, teaching evaluation and other aspects, learning interest and to stimulate the enthusiasm of the students; Mei Rong[7] put forward the reform scheme to improve the teaching of university computer foundation curriculum Science Quality, by construct a teaching content system; Information Engineering College of Shijiazhuang University Of Economics[8] discussed the reform and practice in teaching content, teaching mode, teaching method, etc. However, teaching and student common basic course of computer specialty teaching reform of combination of practice rarely mentioned.

By selecting two typical non-computing majors, accounting major and English major, we make a full investigation on the computer applications requirement and analyze what computer knowledge and ability for subsequent courses in the professional learning and employment requirements, highlight the emphasis in improving professional application ability and computer knowledge.

\section{Problems in Current Teaching mode of Public Computer Course}

At present, the teaching effect of public computer course in universities is not so good, combining my actual teaching situation in Shangdong women's university. There are mainly the following two aspects.

Overlook Different Individual Needs. Current teaching mode is a "make it rigidly uniform" model, regardless specific majors. Almost of all students whatever they major in received the same public computer education structure. But the fact is that the depth of the computer basic knowledge varies for different students by geographic environment and family factors. According to current teaching system, there is a uniform teaching schedule to students of different majors. This model makes some students feel "learned not to use, useful not learned", but other students think the schedule was too slow progress which lead to boredom, so that caused the waste of educational resources and short of computer knowledge of structure for non-computer students, which reduced their passion and confidence in using computer in the field as an auxiliary tool. Consequently it is not conducive to the promotion and development of information technology.

Insufficient Combination of Teaching Content and Professional Practice. From the analysis of the teaching content in recent years, the teaching content of public computer course only extract the simple part from computer professional subjects. It is difficult for teachers to connection with different professional practice and delivers to students in simple language in the teaching process. Thus the public computer education cannot satisfy the demand of students majoring in computer application skills.

Based on the above, the research and reform of public computer basic course teaching has become a pressing task at present. Public basic computer education goal should transform from the past operation skill training gradually to the knowledge and ability as well as the "computer consciousness", combined with the specific professional direction in the basic platform of public computer teaching, which let the students understand the computer as an important role for the professional tools, process and method, familiar with the method using computers to solve professional problems and master the way to obtain professional software.

\section{Reform of Teaching Content, Goal and the Main Features}

According to our investigation, accounting majored students mainly need to master Excel, one of 
components in Microsoft Office software and other accounting software, while English majored students mainly need to skilled in application of Internet, such as application of different browser, and Word, the other components in Microsoft Office software, to process English documents.

Combined with Specific Direction Teaching Model. Discard the existence of "make it rigidly uniform" computer public basic course teaching mode, according to the different professional construction of different computer public basic curriculum system structure, the similar and different students with different teaching schedule. To make students feel learned can be used. Make full use of educational resources, improve non-computer students' computer knowledge structure, improve their use of computer in the field as a tool of enthusiasm and confidence, and help the promotion and development of information technology.

Combined Teaching Contents with Specific Professional Direction. The teachers in the teaching process, the professional practice, and the expression for students to use simple language, to make education better computer public basic to meet the students demand for computer application skills. For example, the accounting students, Excel and their accounts are combined, so that students understand the computer as an important role in their professional tools, process and method, familiar with computer to solve professional problems, grasp the way to obtain professional software. According to the demand for professional application design and development of teaching contents, different multimedia courseware and experiment guide book.

To change the traditional "make it rigidly uniform" teaching ideas, the design is suitable for different professional teaching content; stimulate the students' autonomous learning ability and positive thinking ability. The purpose of design and professional relevant meaningful questions, guide the students to active thinking. The abstract concepts and theoretical difficulties, the computer public basic course through guide show, students answer the questions, seek the way and method to solve the problem from a different angle, so as to guide the students to analyze and solve problems independently.

\section{The Effect of Reform}

Effect of course expected is based on the platform of public based on the combination of the computer professional teaching specific direction, to improve the basic application of computer master students of non computer specialty, and use this tool to find professional computer problem, ability to solve professional problems, as follows:

First, improve students' autonomous learning ability, to adapt to the development of IT technology change rapidly. Second, cultivate students' communicative ability and the consciousness of active service, information technology infrastructure to become the daily operation of the enterprise trend. Third, train students' awareness of network security. Finally, improve the ability of using computer to discover problems and solve professional problems.

\section{Summary}

The curriculum reform mainly took skill requirements for different major into consideration , which not only improved students' overall level of computer basic knowledge and their practical ability and creative ability, but also provide a reference for relevant institutions.

\section{Acknowledgements}

This work was financially supported by National Teachers' scientific research fund (CTF120804), and Program of the teaching reform of public courses of computer in Higher Vocational Colleges ([2012]38-17) sponsored by Shandong Province Office of Education. 


\section{References}

[1] Y.G. Yang, K.J. Wu, W. Xu, et al, University public computer course teaching reform research and practice, Computer Era, vol. 11(2005), p. 80

[2] Y. Ma, University computer basic teaching reform, Journal of Daqing Normal University, vol. 6(2011), p. 114-117

[3] L.J. Wang, D.S. Liu, L.P. Zhang, "Courses" public computer basic construction and practice, computer education, vol. 22(2011), p. 88

[4] M. Chen, Y.M. Tao, Local universities adapt to the "excellence" of the public computer curriculum reform, computer education, vol. 10(2012), p. 84

[5] Z.R. Ni, Based on the cyber source utilization of teaching reform on "computer [J]. Journal of Jinan Vocational College, vol. 2(2012), p.75

[6] G. Wang, Research and practice of the teaching mode of higher vocational computer public basic course, Journal of Hubei Radio and TV University, vol. 6(2012), p. 32-33

[7] R. Mei, "Basic computer" teaching problems and Countermeasures, Journal of Inner Mongolia University for the Nationalities, vol. 2, p. 32-33

[8] Z.F. Zhao, The teaching reform of computer base in University, Science and Education Journal, vol. 3(2012), p. 60-61 